\title{
Busy Book Media Development In Introducing Early Children's Lampung Language at Tk Bina Pertiwi Katon State Pesawaran
}

\author{
Sri Primartin \\ primtinsri21@gmail.com \\ Institut Agama Islam Ma'arif NU (IAIMNU) Metro Lampung \\ Leli Fertiliana Dea \\ leli.f.dea@gmail.com \\ Institut Agama Islam Ma'arif NU (IAIMNU) Metro Lampung \\ Muhammad Yusuf \\ yusufiaimnu@gmail.com \\ Institut Agama Islam Ma'arif NU (IAIMNU) Metro Lampung
}

\begin{abstract}
Knowing the local language has been introduced from an early age so that children do not forget their respective regional languages, including the regional language of Lampung. Introducing the Lampung language starting from counting in the Lampung language, singing, and mentioning the simple vocabulary of the Lampung language. The aim of this research is to develop the Busy Book media as a learning medium to introduce the Lampung language for early childhood, see the feasibility of the Busy Book as a learning medium to introduce the Lampung language in child. Research in the form of R \& D taken from the development of Brog and Gell, the subject of this research is TK Bina Pertiwi Desa Pejambon, Negeri Katon District, Pesawaran Regency with a questionnaire-based research instrument that is validated by material experts and media experts, and teachers at Bina Pertiwi Kindergarten, Pejambon Village, Negeri District. In Katon Pesawaran District, the type of data produced is qualitative data which is analyzed with new criteria of assessment to determine the quality of the Busy Book being developed. The result of this research is that the Busy Book media as a learning medium for early childhood in Bina Pertiwi Kindergarten is very feasible to use and can also improve Lampung language skills in early childhood.
\end{abstract}

Keyword : Media, Busy Book, Lampung language.

(C) 2021 Sri Primartin, Leli Fertiliana Dea, Muhammad Yusuf

This work is licensed under a Creative Commons Attribution-ShareAlike

\section{INTRODUCTION}

Indonesia is a country that has many unique regional languages or called the mother tongue, one of them is Lampung language, Lampung language is a regional language used by the people of Lampung as a means of communication. Lampung 
language is one of 746 regional languages in Indonesia. The true speech of the Lampung language is not only in Lampung but also in the provinces of South Sumatra and Banten.

Katubi, revealed that the Lampung language does not know the levels as found in Javanese or Sundanese. However, like other languages, Bahasa Lampung has a variety of formal and informal. Based on the map, Bahasa Lampung has two subdialects. First, subdialect A (fire) which is used by the people of Lampung Peminggir/Saibatin. Second, subdialect o (nyo) which used by the people of Lampung Pepadun. (Inawati 2017)

According to Tarigan. This is explained in the purpose of learning Lampung language which expects students in schools to be proficient and skilled, speaking skills become very important despite the fact that learning for this special material has not been able to be mastered

by students in school. The ability of students in using the Lampung language is still very low, especially in the ability to speak.(Rulia 2012)

The diversity that is the main center in the province of Lampung is the diversity of the language of Lampung that is increasingly abandoned and almost extinct. (Putri 2018) and not fluent in Lampung language. Even the use of Lampung language is mostly just a language in homes. (Hartono, Pitoewas, and Yanzi 2016)

Therefore in the aspect of language development we must also introduce our local language at an early age, so that at this time children can know some vocabulary or know the language of the area where we live, such as Bahasa Lampung. Language intelligence enters into the aspect of language development for children at an early age, it is confirmed that children's language development needs to be developed since the child starts from the age of 0-8 years. In the material of children's language development, then adapted to the child's age. (Nur Tanfidiyah and Ferdian Utama 2019) Many early childhood education that only applies learning to play while learning and provide character education only, so forget to introduce the local culture or language from an early age. Educational services must be done from an early age because, as we all know that early education will determine further education. (Yusuf 2017) No exception, the introduction of regional languages such as Lampung language must be taught since school children in early childhood education or called early childhood education so that children do not forget their respective regional languages. Getting to know the Lampung language is very important for children at an early age, starting from counting with the Lampung language, singing, and saying the simple vocabulary of the Lampung language.

Some of the factors that cause the decline in the use of Lampung language among early children in the district of Lampung are the lack of early introduction of the district language, and the lack of learning media used to introduce the language of Lampung to children.

Based on the pre -observation results that in TK Bina Pertiwi Negeri Katon Pesawaran The learning media available are only textbooks, magazines for them to learn, even no learning media is used to introduce the Lampung language. (Sri Primartin 2021)

So in introducing the Lampung regional language only in do with Using Songs without Using Media, and it results in children easily bored and not interested in the introduction of the Lampung regional language. As a result, the students' enthusiasm in knowing the language of the Lampung district is very low, they prefer to play. 
The introduction of Lampung language is not developed due to the lack of use of media or educational games in learning so that children are less interested in the introduction of Lampung language, as teachers we must have creative thinking in creating an interesting learning media will make children enthusiastic and not bored in activities learning. (Sri Primartin 2021)

Based on the results of these observations, researchers want to conduct research and development of a product called Busy Book which is inspired by the book Play and Learn by a doctor, Dr. Meta Hanindita, Sp.A, in this book Play and Learn contains about parenting how parents provide games that can stimulate aspects of child development. In this book, Dr. Meta Hanindita, Sp.A made an activity book for his 4 -year -old child called Nay's book. This book provides many benefits as a means of stimulating children's growth and development. (Nurlaela 2018)

Development of Busy book developed by researchers on the introduction of Lampung language such as counting, recognizing color names and simple vocabulary in Lampung language. Busy Book previously only contained pictures with combinations color. What the child will tell is in accordance with what they see in the picture. The innovation that the researcher did was that there was a worksheet containing numbers and colors where the child would match the words of the Lampung language.

In connection with this, the author is motivated to conduct research and development with the title "Development of Busy Book Media in Introducing the Language of Lampung Early Childhood Kindergarten Bina Pertiwi Negeri Katon Pesawaran".

\section{METHODOLOGY}

This research is in the form of $R \mathcal{E} D$ taken from the development of Borg and Gell, subject of this research is TK Bina Pertiwi Pejambon, Negeri Katon, Pesawaran Regency with an assessment instrument in the form of a questionnaire validated by material experts and media experts, and teachers at TK Bina Pertiwi Pejambon, Negeri Katon Pesawaran, the type of data produced is qualitative data which is analyzed with the guidelines for the assessment criteria to determine the quality of the Busy Book being developed.

\section{RESULTS AND DISCUSSION}

The Busy Book learning media product that will be developed aims to produce an educational game tool product that is suitable for use in the learning process of 5-6 year old children at TK Bina Pertiwi Desa Pejambon. This product was developed to solve the problems of learning the introduction of the Lampung language for early childhood in the classroom and outside the classroom. This research was conducted using a research and development method or called Research and Development). From the results of observations to schools in Bina Pertiwi Kindergarten, they have not used Busy Book media in introducing the Lampung language for early childhood. In Bina Pertiwi Kindergarten, in introducing the Lampung language, they still use songs only as a medium of learning. The first step taken by the researcher was to determine the theme to be created and then design the product using flannel. 


\section{Product Validation}

The calculation of the average number of validation results obtained has the purpose to know the feasibility of busy book learning media in introducing lampung language early childhood.

\section{a. Validation Results By Material Experts}

From the results of the validation carried out by material experts in the form of a questionnaire with 6 question indicators, it got a total score of 20 with an average result of 3.33 and obtained a very feasible category. This validation is carried out so that the media Busy Book becomes a quality product. Following are the results of the material expert validation assessment in the form of a graphic based on the average score obtained.

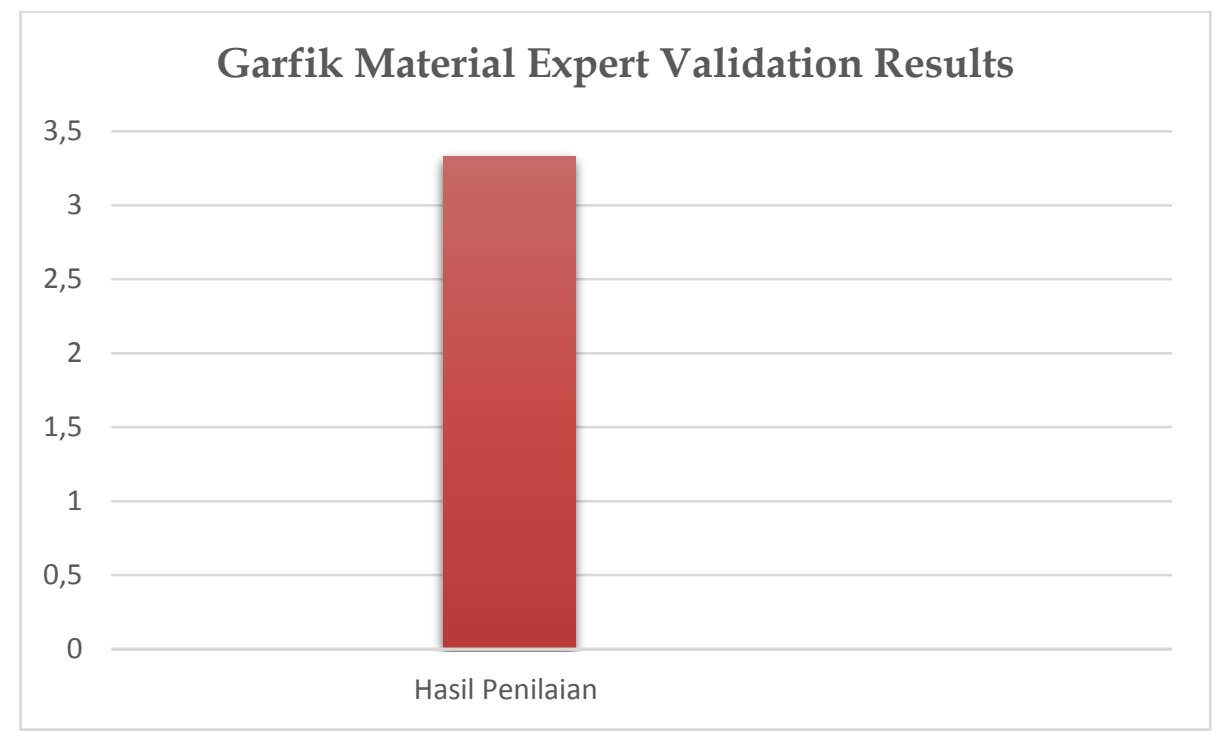

Figure 1.1 Garfik Material Expert Validation Results

b. Validation Results By Media Experts

Based on the results of the assessment carried out by media experts in the form of a questionnaire, the results obtained were a total of 25 with 7 question indicators getting a total score of 25 with an average score of 3.57 and got the very feasible category. Based on these results, it can be seen that themedia is Busy Book suitable for use in introducing the Lampung language to early childhood, here are the results of the media expert validation assessment in graphical form: 
Busy Book Media Development In Introducing Early Children's Lampung Language at Tk Bina Pertiwi Katon State Pesawaran

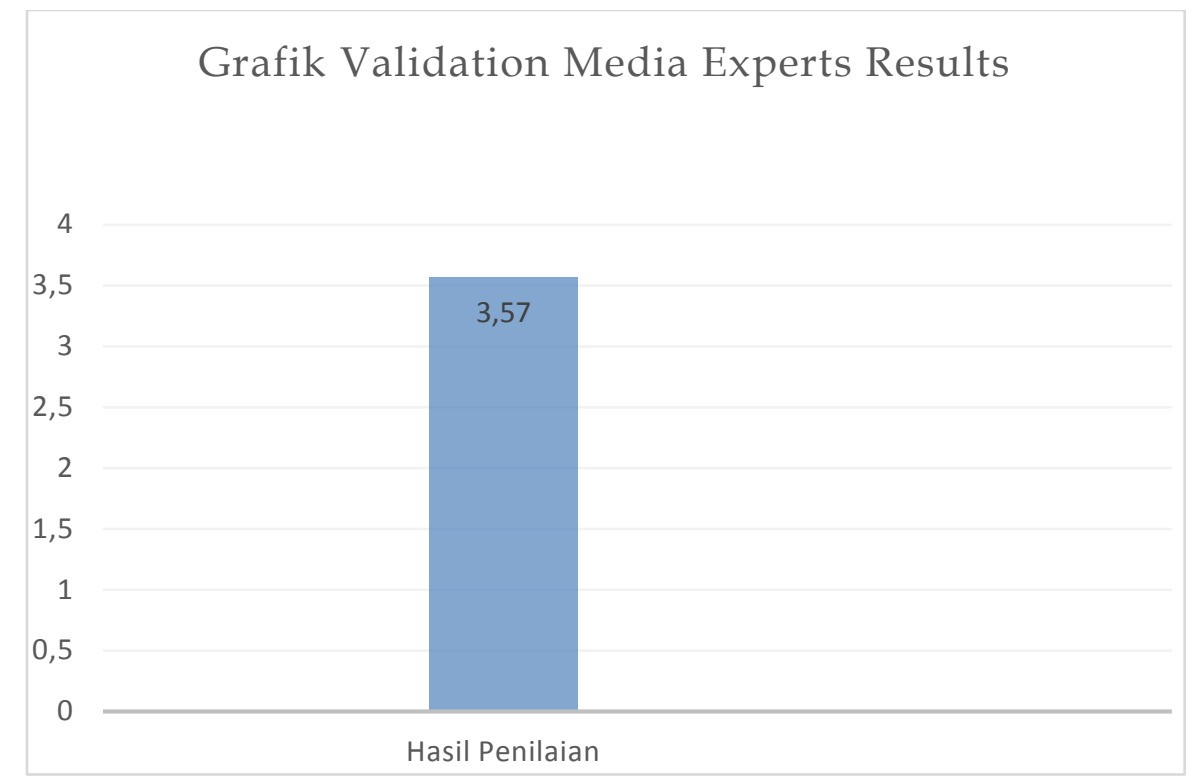

Figure 1.2 Validation Media Experts Results

c. Trial

In research and development, the researchers conducted tests to evaluate the response of teachers and students to the media Busy Book in introducing language Lampung early childhood development, test media usage Busy Book is done by teachers and students who performed in the small group trial (limited). The results obtained are then processed to get the final result of media usage test Busy Book, from the average score and category. The results of the calculation data obtained aim to determine the feasibility of media Busy Book to introduce the Lampung language for early childhood.

Limited trials are carried out such as learning in class, so that teachers and students can understand how to use the Busy Book. The trial was carried out in class B Bina Pertiwi Kindergarten, after conducting the trial, the teacher made revisions in the form of suggestions and input on the media Busy Book to make it even better. The following are the results of teacher and student trials in limited trials.

Trial Media Busy Book

In the introduction of the Lampung language for early childhood, it is necessary to have a learning media that can be used in introducing the Lampung language, learning media is an intermediary in providing material to students in learning activities, but usually the media used in learning in paud is only printed media such as magazines and others. Therefore this research will develop the Busy Book media for learning media, along with the daily learning plan (RPPH) using the media Busy Book at TK Bina Pertiwi Pejambon village:

1) Theme

This research was conducted on Thursday, November 19, 2020, in children aged 5-6 years old in Bina Pertiwi Kindergarten with the theme "Myself".

2) Material

Materi yang terdapat dalam tema diri ku adalah sebagai berikut:

a) The material contained in my theme is as follows:

"counting in Lampung language" 
b) Pasting numbers with words in Lampung language

c) Mention warrants in Lampung languag

d) Mentioning limbs in Lampung language

3) Opening (15 Minutes)

Activities conducted at the opening are as follows:

a) Greetings, and prayers before the activity

b) Opening greetings with Lampung language "Tabik Pun"

c) Absent students, bernyani about counting in Lampung language, pat-pat pronunciation and move freely

d) The teacher explains the theme that will be learned today "Myself".

e) Teachers and students conduct question and answer sessions on the theme of "Myself".

4) Core Activities (60 Minutes)

a) Teacher prepares Busy Book media

b) Children are invited to play about numbers in Lampung language in Busy Book media

c) Children are required to order warana in Lampung language designated in the clockwork game in Busy Book

d) Children are introduced to the limbs in Lampung language in Busy Book.

5) Rest (15 Minutes)

a) Tidy up learning equipment

b) Q\&A about the material that has been submitted

c) Pray before eating

d) Wash your hands and eat together

6) Closing (15 Minutes)

a) Pray before going home

b) Review the lessons already given

c) Provide a theme that will be discussed tomorrow

d) Greetings and silence

It is very important to introduce the Lampung language to early childhood so that children know the local language and do not forget the local language.

However, at Bina Pertiwi Kindergarten, the introduction of Lampung language is very hampered and difficult to convey by students because of the lack of learning media used, and students are not interested in learning to know the Lampung language. Therefore, the researcher conducted a trial using the media Busy Book in introducing the Lampung language to early childhood. With the following steps:

a) The child is given a clear explanation of what is in the Busy Book.

b) Children are introduced in advance the contents of the busy book about numbers, colors, and limbs in Lampung language according to the following picture 


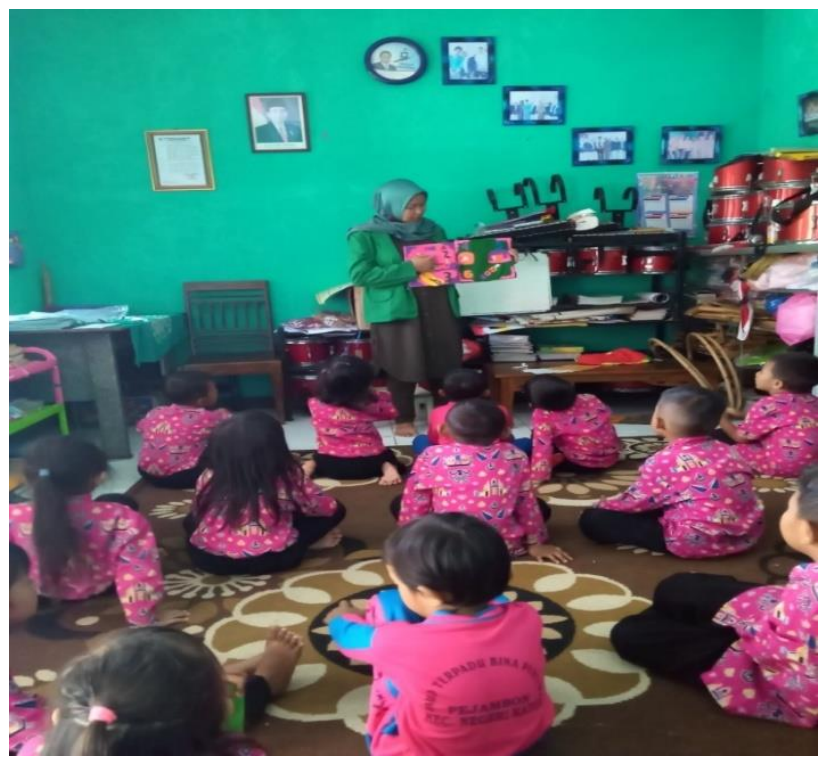

Figure 1.3 Introduction Busy Book Content

Based on the picture the teacher explains the material contained in theBusy Book, starting from the recognition of numbers, colors and body parts in the Lampung language so that children can first understand the material to be delivered and can work on the material contained in the Busy Book.

c) The child is led to do every activity in Busy Book, the teacher asks the child to open the first page about the game of knowing numbers in Lampung language.

Based on the results of the study, the first step for children to be introduced to numbers in Lampung language with games in the Busy Book, first the children were taught about numbers in Lampung using songs, then the children were taught how to play it by releasing one of the numbers in the busy book and matching it with the word. numbers in the Lampung language as shown below:

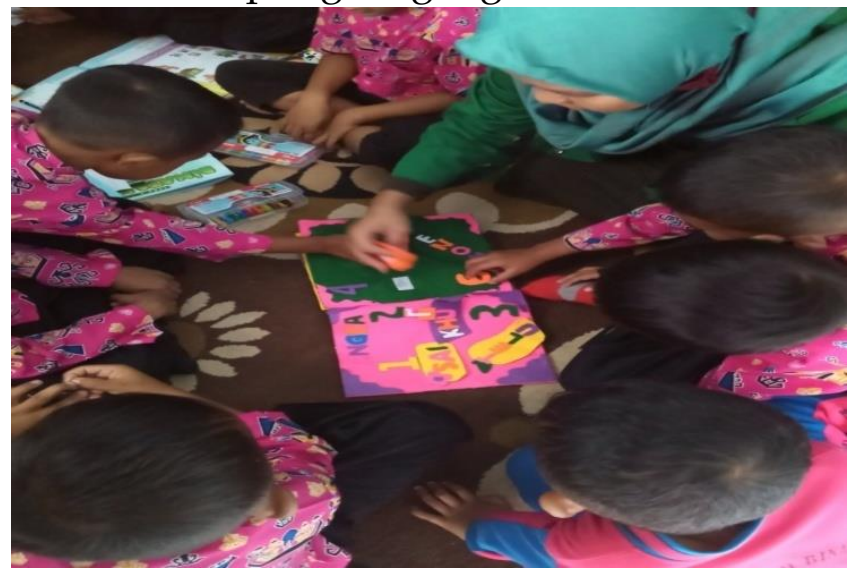

Figure 1.4 Introduction to Numbers in Lampung Language

From this picture the children are divided into 2 groups of boys and girls, in the group the children are asked to do a game to recognize numbers in the Lampung language, by matching numbers and words in the Lampung language. 
d) Furthermore, the teacher explained about the introduction of warrants in Lampung language in Busy Book.

Based on this research, the child was told the recognition of colors in the Lampung language with a clock game in Busy Book, the needle was rotated according to the teacher's instructions, then the child answered what color the clock indicated. With the following image:

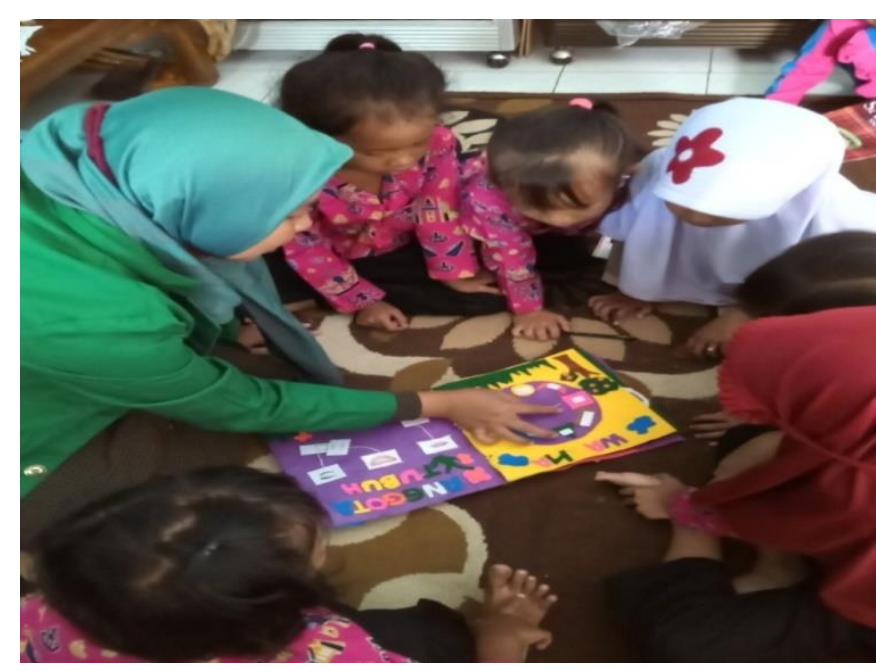

Figure 1.5 Color Recognition in Lampung Language

Based on the picture above. In the group of children, the children were introduced to the introduction of warrants, in this case the teacher turned the clockwise and pointed to the color in the Busy Book, then the child answered what color the needle pointed to, after the child answered the teacher told him the meaning of color in his Lamp language. If the child answers correctly, the teacher will put an asterisk in his hand so that the child feels happy.

e) In the next page, the teacher introduces the limbs in Lampung language in the game in Busy Book.

Based on the results of the research, the teacher introduced the limbs in the Lampung language to the games in the Busy Book. Namely the magic card, this magic card was rolled back first by the teacher then the child was asked to open the card and answer what picture of the limb was on it card. With the following picture:

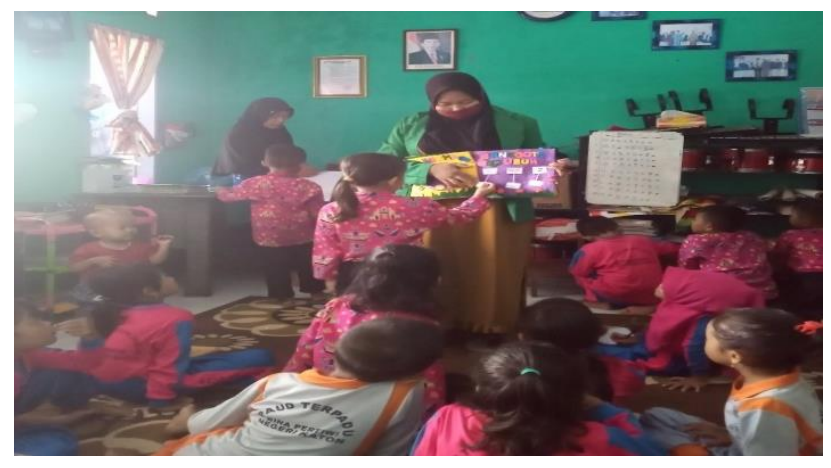

Gambar 1.6 Pengenalan Anggota Tubuh Dalam Bahasa Lampung. 
Based on the picture, the teacher invites the child to play to know the limbs in Lampung language, the teacher closes one of the limb cards in the busy book, then one of the children is asked to come forward to open the card and answer what body member is on the card. Then the teacher tells the meaning of body parts in the Lampung language.

f) After the learning activity is complete the teacher will give an asterisk to the child who answers correctly

In this study, teachers will give asterisks to children who can answer and do tasks in Busy Book. So that the child feels happy and does not feel bored in the learning process. With the following figure:

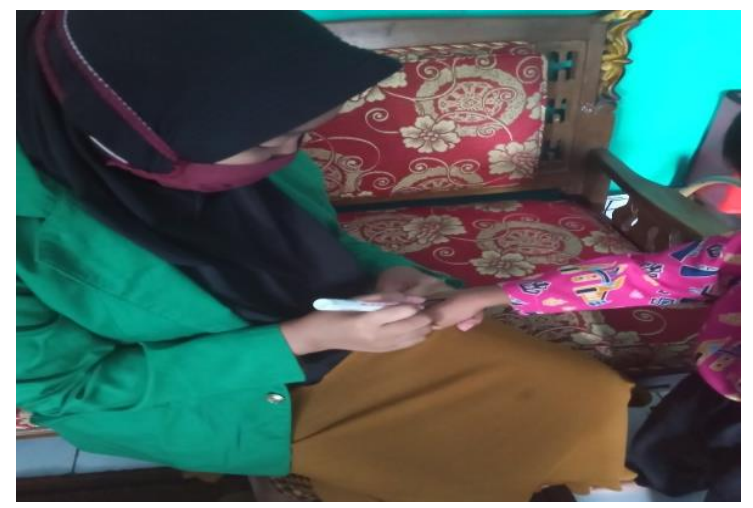

Figure 1.7 Giving Grades to Children Who Can Do Tasks

From the picture above, the teacher gives grades to children who usually do tasks in the Busy Book, in the form of a star in the hand of a child who can do the tasks in the Busy Book correctly using a marker, so that the child feels happy and doesn't get bored in the learning process. introducing the Lampung language. It can be seen that the steps to use media Busy Book are in accordance with the existing theory. The condition of students in Bina Pertiwi Kindergarten, during the teaching and learning process, before using media Busy Book students did not pay attention to the teacher's explanation and preferred to play alone rather than pay attention to the teacher. Based on the pre-survey data, the child's ability to recognize the Lampung language, children aged 5-6 years at Bina Pertiwi Kindergarten can be said to have not developed, based on the following table:

Tabel 1.1

Pre-observation data Development introduces Lampung language

Early childhood at Bina Pertiwi Age Kindergarten (5-6) Years.

School year 2020/2021

\begin{tabular}{|c|c|c|c|c|c|}
\hline \multirow[t]{2}{*}{ No } & \multirow[t]{2}{*}{ Nama } & \multicolumn{3}{|c|}{ Indikator } & \\
\hline & & 1 & 2 & 3 & KET \\
\hline 1. & Amira anindita.m & $\mathrm{BB}$ & $\mathrm{BB}$ & $\mathrm{BB}$ & $\mathrm{BB}$ \\
\hline 2. & Azkia anandita saufa & MB & MB & MB & MB \\
\hline 3. & Al-mada syaputra & BB & BB & BB & BB \\
\hline 4. & Azka fratama & $\mathrm{BSH}$ & $\mathrm{BSH}$ & $\mathrm{BSH}$ & $\mathrm{BSH}$ \\
\hline 5. & Muhamad nazril atala & MB & MB & MB & MB \\
\hline
\end{tabular}




\begin{tabular}{|l|l|l|l|l|l|}
\hline 6. & Gali prayogo & BB & BB & BB & BB \\
\hline 7. & Dirga fitrah karisma & BB & BB & BB & BB \\
\hline 8. & Farhan ananda & BB & BB & BB & BB \\
\hline 9. & Fitri amelia & BB & BB & BB & BB \\
\hline 10. & Indri natalia & MB & MB & MB & MB \\
\hline 11. & Kalila rifda & BB & BB & BB & BB \\
\hline 12. & Lintang aura putri & BB & BB & BB & BB \\
\hline 13. & Muhamad ilham & BB & BB & BB & BB \\
\hline 14. & Naufal afkar & BB & BB & BB & BB \\
\hline 15. & Naufal dani abiyu & BB & BB & BB & BB \\
\hline 16. & Quissa hayatul husna & BB & BB & BB & BB \\
\hline 17. & Rania khumaira zidny & BB & BB & BB & BB \\
\hline 18. & Rama tri julia & BB & BB & BB & BB \\
\hline 19. & Satria atmajaa & BB & BB & BB & BB \\
\hline 20. & Wagito arya maulana & BB & BB & BB & BB \\
\hline 21. & Yudha darma prataama & BB & BB & BB & BB \\
\hline 22. & Muhamad pradja alvero & BSH & BSH & BSB & BSH \\
\hline 23. & Zahra aulia & BB & BB & BB & BB \\
\hline & & & & & \\
\hline
\end{tabular}

Source : results of weekly learning research for children in the 2020/2021 school year.

Description :

BB : Undeveloped

MB : Start Growing

BSH : Develop As Expected

BSB : Very Well Developed

Based on the table, it is known that the introduction of the Lampung language to children aged 5-6 years in Bina Pertiwi Kindergarten is still classified as underdeveloped, this is known from the number of children who are still classified as underdeveloped as many as 17 children, starting to develop as many as 3 children, and 2 children developing accordingly. hope.

However, after a trial using media Busy Book for children aged 5-6 years in Bina Pertiwi Kindergarten, children's cognitive development has increased. From the results of research, there is an increase in the assessment of the introduction of the Lampung language in early childhood, by using the Busy Book the children feel happy and happy so that there are 11 children who get grades starting to develop (MB), 5 children develop according to expectations (BSH), and 7 children develop very good (BSB).

This research was conducted on children aged 5-6 years at Bina Pertiwi Kindergarten with the first step of making a media product design Busy Book, then the researcher validated the design by material experts and media experts after the two experts stated that this media was suitable for use. Furthermore, researchers conducted product trials on children aged 4-5 years at Bina Pertiwi Kindergarten. After conducting a limited trial, it was proven that the Busy Book media could improve the introduction of the Lampung language in early childhood. 
d. Results of Limited Trial of Busy Book Media Use By Teachers

In this trial, the researcher gave questions in the form of a questionnaire containing 5 question indicators regarding the media Busy Book. From the assessment, it is written that the lowest score starts from 1 and the highest score is 4 , the product use trial was carried out by the Kindergarten teacher in class B, based on the results of the research trial on media, Busy Book it obtained a total value of 19 with an average value of 3.80.media Busy Book falls into the very feasible category. The following are the results of the assessment in graphical form.

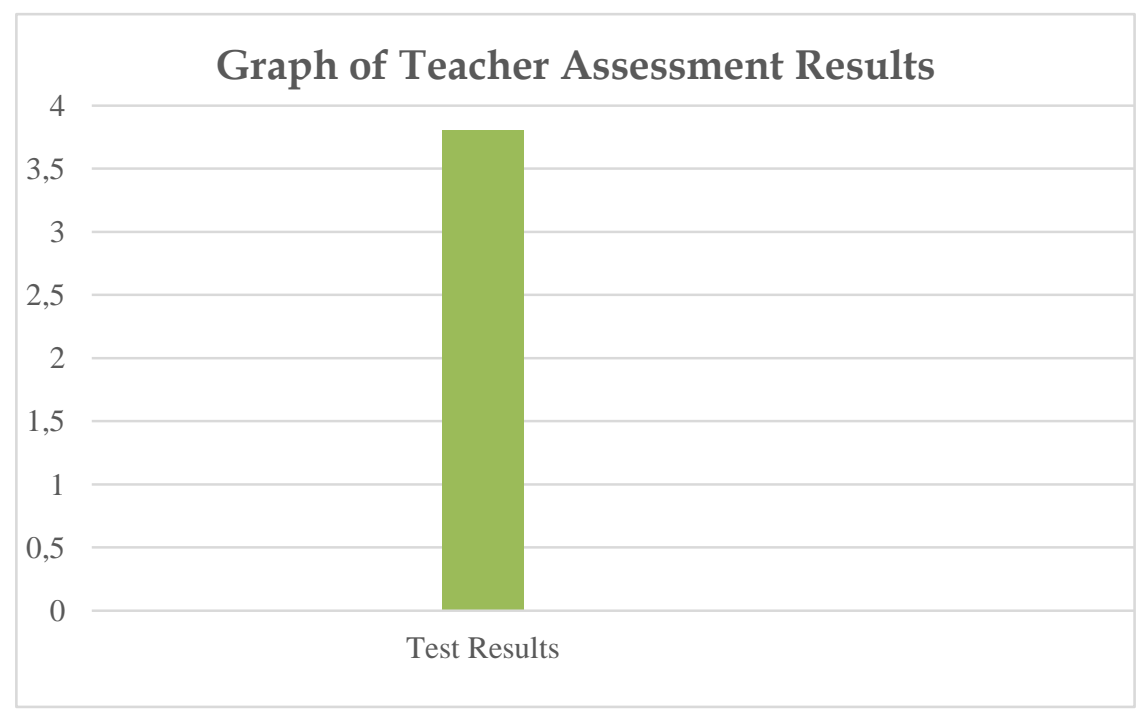

Figure 1.9 Teacher Assessment Results

From the graph above, it can be concluded that the average value obtained is 3.80 with a very decent category, so busy book media is very worthy to be used as a medium of early childhood learning in getting to know Lampung language.

e. Hasil Uji Coba Media Busy Book Yang Dilakukan Oleh Siswa.

In this study the researcher gave 5 question indicators regarding themedia Busy Book conducted in class B, from the results of the table of limited trials conducted by students, it can be concluded that the quality of themedia Busy Book got a total score of 18 with an average score of 3.60 and obtained a very decent category. From these results it can be explained in the following graph. 


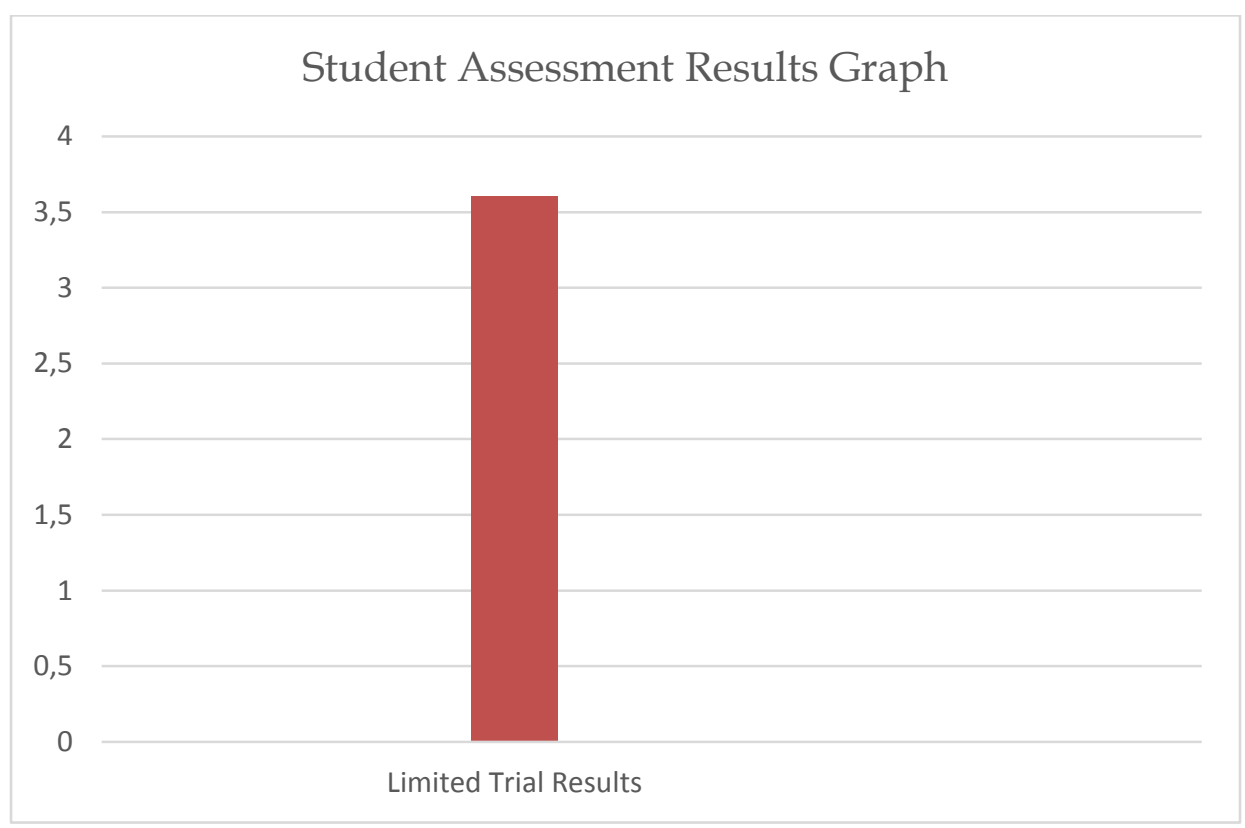

Figure 1.10 Student Assessment Results

Based on the graph above, it can be concluded that themedia Busy Book that has been developed is very suitable for use as a medium for early childhood learning. And this media gets an average score of 3.60 in the very feasible category.

The following are the results of the assessments from material experts, media experts, teachers and students in graphic form. the following graphic form.

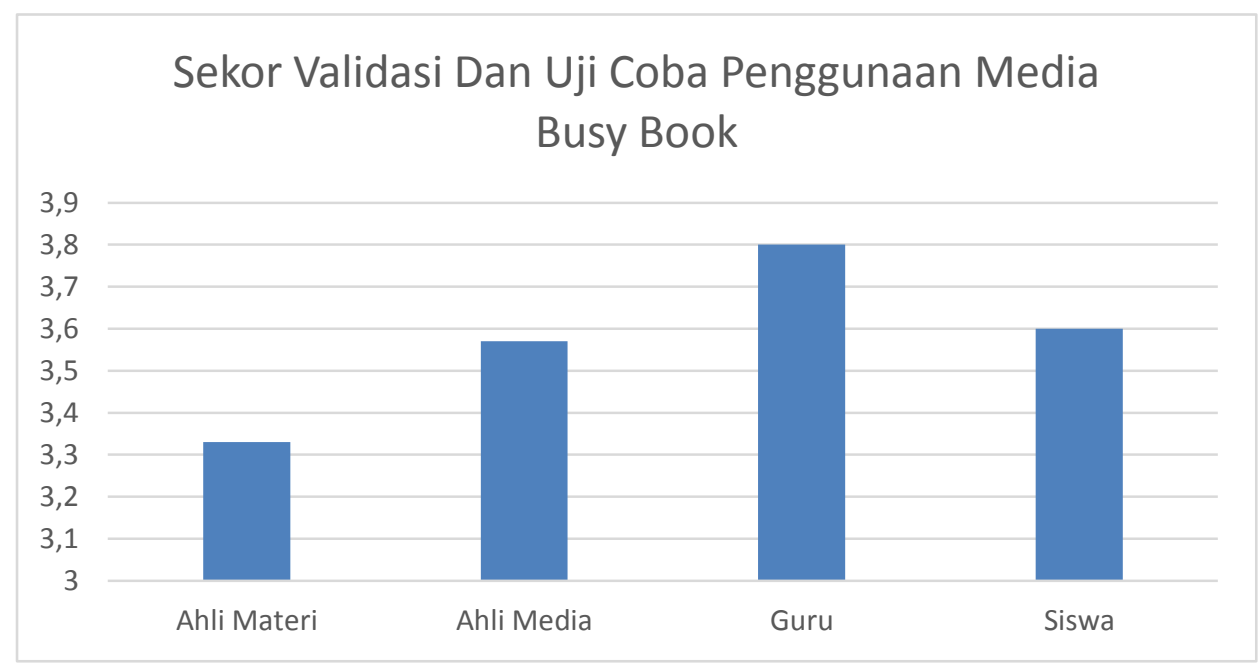

Figure 1.11 Assessment Results

From the graph above it can be concluded that the media material expert's assessment Busy Book obtained an average score of 3.33, the media expert got an average score of 3.57, from the teacher's assessment a score of 3.75 , and from the student's assessment a score of 3,58 with the very feasible assessment category, it can be concluded that overall from the graph above shows that the media Busy Book developed is declared feasible and can be used in schools as a medium for early childhood learning. 
Busy Book Media Development In Introducing Early Children's Lampung Language at Tk Bina Pertiwi Katon State Pesawaran

\section{f. Advantages and Disadvantages of Products}

The products produced from the media Busy Book are products made from flannel which are formed with various pictures of fruit, houses and vehicle shapes, and this Busy Book media contains the recognition of numbers, colors and body parts in the Lampung language as a learning medium for early childhood, with using Busy Book learning media makes children feel happy, not bored in learning activities and makes children more active with game activities in Busy Book. However, this product has advantages and disadvantages, including:

a. Advantages

1. This learning media can be used in introducing Lampung language to early childhood.

2. This learning medium has interesting colors and shapes.

3. This learning media contains 3 kinds of games about introducing Lampung language in early childhood.

b. Disadvantages

The disadvantage in busy book media is in busy book media desian about the introduction of numbers in Lampung language because it only has 10 numbers introduced in Lampung language and limited color and limb recognition in Lampung language.

\section{CONCLUSION}

Conclusion provides a summary of the description of the results and discussion, referring to the research objectives. Based on these two things, new ideas are developed which are the essence of the research findings.

The conclusion from research and development is that a product has been developed Busy Book as a learning medium in introducing the Lampung language for early childhood. The Busy Book is made from flannel cloth which contains the introduction of numbers, colors and body parts in Lampung language, and the activities in the Busy Book can introduce numbers, colors and alphabets to children and to introduce the Lampung language to early childhood, with the use of media learning as follows 1. The child is given an explanation of what the contains Busy Book, 2.The children are led to do each activity from the page Busy Book, the teacher asks the children to open the first page about the game to recognize numbers in the Lampung language. 3. Then the teacher explains about color recognition in the Lampung language in the Busy Book. On the next page the teacher introduces the limbs in Lampung language to the games in the Busy Book.5. After the learning activity is complete the teacher will put an asterisk on the hand of the child who can answer correctly.

the evaluation of the material expert validator got an average rating of 3.33 in the "Very Appropriate" category, from the media expert an average rating of 3.57 with the "Very Appropriate" category, the assessment of the Bina Pertiwi Kindergarten teacher got an average score of 380 with the "Very Appropriate" category, and from the limited trial assessment conducted by students obtaining an average score of 3.60 in the "Very Eligible" category. 
The use of Busy Book media for children aged 5-6 years at Bina Pertiwi Kindergarten Pejambon Village in introducing the Lampung language for early childhood, based on pre-survey data the children obtained 17 underdeveloped categories, 3 children started developing category, and developed according to the expectations of 2 people. Meanwhile, after using the Busy Book media in introducing the Lampung language to early childhood there is an increase in the learning process, with the children's assessment as follows, there are 11 children who have started to develop, 5 children develop according to expectations and 7 children develop very well.

\section{ACKNOWLEDGEMENT}

Thank you for helping the completion of and supporting our research to TK Bina Pertiwi Katon State, Pesawaaran. We would also like to thank JCD: Journal of Development for accepting and publishing the results of the research we studied.

\section{REFERENCES}

Hartono, Hadi, Berchah Pitoewas, and Hermi Yanzi. 2016. “Peranan Mulok Bahasa Lampung Dalam Upaya Pelestarian Bahasa Dan Budaya Lampung." Jurnal FKIP Unila 4(3). https:/ / digilib.unila.ac.id/22310

Inawati, Iin. 2017. “Tantangan Dan Strategi Praktis Pemertahanan Bahasa Lampung.” Jurnal Pesona 3(2):163-73. https:/ / doi.org/10.26638/jp.445.2080

Nur Tanfidiyah, and Ferdian Utama. 2019. “Mengembangkan Kecerdasan Linguistik Anak Usia Dini Melalui Metode Cerita." Golden Age: Jurnal Ilmiah Tumbuh Kembang Anak Usia Dini 4(3):9-18. https:/ / doi.org/10.14421/jga.2019.43-02

Nurlaela, Lela. 2018. “Pengembangan Media Pembelajaran Busy Book Dalam Meningkatkan Kemampuan Bahasa Anak Usia Dini Di Play Group Islam Bina Balita Way Halim Bandar Lampung." UIN Raden Intan Lampung. http:/ / repository.radenintan.ac.id/5720/1/skripsi.pdf

Putri, Nandita Wana. 2018. “Pergeseran Bahasa Daerah Lampung Pada Masyarakat Kota Bandar Lampung." PRASASTI: Journal of Linguistics 3(1):83. https://doi.org/10.20961/prasasti.v3i1.16550

Yusuf, Muhammad. 2017. The role of education islam for education sex and prevent sexual abuse in children (case studies in ra metro city lampung). https:/ / www.researchgate.net/profile/Ahwy-Oktradiksa2/publication/312947340_REINTERPRETATION_OF_NATIONAL_EDUCATIO N_STANDARD_IN_PLANNING_OF_QUALITY_IMPROVEMENT_FOR_MAD RASAH_IBTIDAIYAH_FLAGSHIP/links/588aeb6c92851cc55d3d0e34/REINTE RPRETATION-OF-NATIONAL-EDUCATION-STANDARD-IN-PLANNINGOF-QUALITY-IMPROVEMENT-FOR-MADRASAH-IBTIDAIYAHFLAGSHIP.pdf\#page $=152$ 